\title{
Recession Signals: The Yield Curve vs. Unemployment Rate Troughs
}

\author{
Kevin Kliesen, Business Economist and Research Officer
}

n early May 2018, The Wall Street Journal asked professional forecasters to predict when the next recession would begin. Nearly 6 in 10 answered that the next recession will begin sometime in 2020. If so, the current business expansion will have eclipsed the 1991-2001 expansion as the longest on record. Economists and policymakers look at several leading indicators when attempting to predict a slowdown or outright contraction in economic activity. Two stand out: the slope of the yield curve and the direction of the unemployment rate. The purpose of this essay is to ascertain the predictive power of these two economic indicators.

Both the yield curve and the unemployment rate tend to reliably predict recessions.

Economists have known for quite some time that yield curve inversions tend to be reliable predictors of business contractions (recessions). ${ }^{1}$ An inversion occurs when the yield on short-term Treasury securities exceeds the yield on long-term Treasury securities. Typically, an inversion occurs when the Federal Open Market Committee (FOMC) is raising its short-term policy rate to counteract rising inflation pressures.

Figure 1 plots the difference between the yield on 10-year Treasury securities and the yield on 3-month Treasury securities at a monthly frequency. This yield spread is one commonly used measure of the slope of the yield curve (also known as the term structure) across time. As Figure 1 shows, yield curve inversions have regularly occurred prior to periods of economic recessions since the 1960s. Recession periods are defined by the National Bureau for Economic Research (NBER) Business Cycle Dating Committee. ${ }^{2}$

Some monetary policymakers have become concerned about the recent flattening of the yield curve. ${ }^{3}$ In April 2018 , the slope of the yield curve averaged 1.11 percent, 0.4 percent (40 basis points) below its long-term expansion average of 1.51 percent (since June 1954). The concern

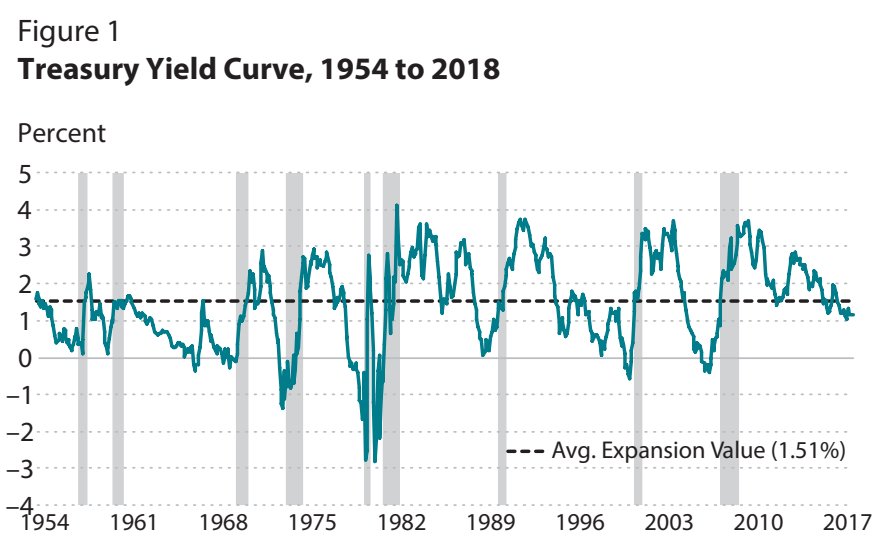

NOTE: Gray bars indicate recessions as determined by the NBER. SOURCE: Federal Reserve Board, U.S. Treasury, and Haver Analytics.

Figure 2

Unemployment Rate, 1954 to 2018

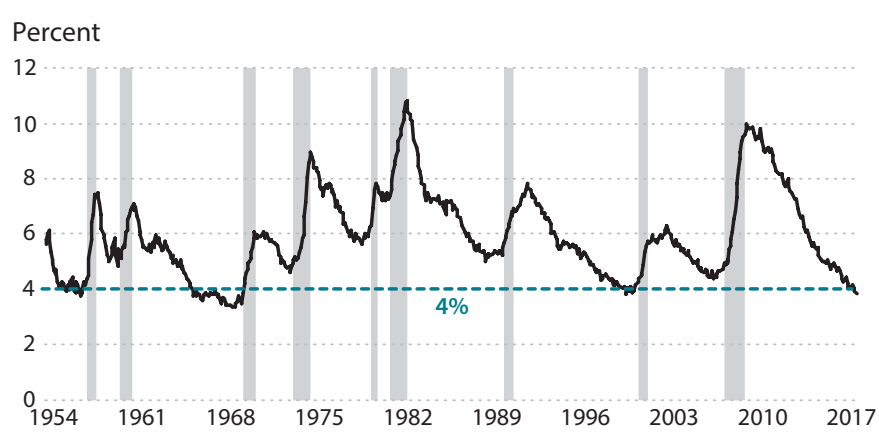

NOTE: Gray bars indicate recessions as determined by the NBER. SOURCE: Bureau of Labor Statistics and Haver Analytics.

about a further flattening of the yield curve slope, or outright inversion, stems from the possibility that several additional increases in the FOMC's federal funds rate target will not be accompanied by increases in the 10-year interest rate.

In contrast to a narrowing of the spread between shortand long-term Treasury yields, a low unemployment rate usually suggests strengthening economic growth. On June 1, 2018, the Bureau of Labor Statistics reported that the unemployment rate (after falling persistently) measured 3.8 percent in May 2018. This is only the third economic 


\section{Unemployment Rate Troughs and Yield Curve Inversions Prior to Business Expansion Peaks}

Unemployment rate trough statistics

\begin{tabular}{|c|c|c|c|c|c|c|c|}
\hline $\begin{array}{l}\text { Unemployment } \\
\text { rate trough }\end{array}$ & Trough month & NBER peak & $\begin{array}{c}\text { Unemployment } \\
\text { rate at } \\
\text { NBER peak }\end{array}$ & $\begin{array}{l}\text { Difference } \\
\text { between } \\
\text { trough month } \\
\text { and NBER peak } \\
\text { month }\end{array}$ & $\begin{array}{l}\text { Change in } \\
\text { unemployment } \\
\text { rate between } \\
\text { trough month } \\
\text { and NBER peak } \\
\text { month }\end{array}$ & $\begin{array}{l}\text { Inversion of } \\
\text { yield curve }\end{array}$ & $\begin{array}{c}\text { Difference } \\
\text { between } \\
\text { inversion month } \\
\text { and NBER peak }\end{array}$ \\
\hline 3.36 & Feb 1969 & Dec 1969 & 3.53 & -10 & 0.17 & Jan 1969 & -11 \\
\hline 4.60 & Oct 1973 & Nov 1973 & 4.85 & -1 & 0.25 & Jun 1973 & -5 \\
\hline 5.61 & May 1979 & Jan 1980 & 6.27 & -8 & 0.67 & Dec 1978 & -13 \\
\hline 7.19 & Dec 1980 & Jul 1981 & 7.24 & -7 & 0.05 & Nov 1980 & -8 \\
\hline 5.04 & Mar 1989 & Jul 1990 & 5.51 & -16 & 0.47 & Jun 1989 & -13 \\
\hline 3.84 & Apr 2000 & Mar 2001 & 4.27 & -11 & 0.43 & Aug 2000 & -7 \\
\hline 4.40 & Mar 2007 & Dec 2007 & 4.97 & -9 & 0.57 & Aug 2006 & -16 \\
\hline
\end{tabular}

Sample-period statistics: episodes since 1957

\begin{tabular}{ccc|cc}
\hline Average & -9 & 0.37 & Average & -10 \\
\hline Maximum & -16 & 0.67 & Maximum & -16 \\
\hline Minimum & -1 & 0.05 & Minimum & -5 \\
\hline
\end{tabular}

SOURCE: Author's calculations based on data from Haver Analytics.

expansion in the past eight (current included) that has registered an unemployment rate below 4 percent (see table). Does the low unemployment rate suggest a different outlook from the narrowing yield spread?

Historically, a trough in the unemployment rate also tends to be a reliable predictor of a business recession. This fact can be visually verified in Figure 2, which plots the civilian unemployment rate for all persons ages 16 and over since June 1954. As seen in Figure 2, the unemployment rate tends to reach a trough shortly before an economic recession. Once the recession begins, unemployment rises sharply. But is an unemployment rate trough a more reliable signal of a pending recession than a yield curve inversion?

The table examines the leading-indicator properties of unemployment rate troughs (left side) and yield curve inversions (right side) since 1969. In each instance, the month of occurrence is compared with the business expansion peak, as determined by the NBER. Since there were no yield curve inversions prior to 1969 , the emphasis will be on the episodes since the 1969-70 recession.

On average, since 1969, the unemployment rate trough occurred nine months before the NBER-determined recession trough, while the yield curve inversion occurred 10 months before. For both series, the maximum lead time is 16 months before the recession-but in different episodes.
The minimum lead times were one month for the unemployment trough and five months for the yield curve inversion. The table also indicates that, on average, the unemployment rate increases by 0.4 percentage points over the eight-month period between the trough and the NBERdefined peak. ${ }^{4}$

Based on this evidence, it appears that both indicators tend to be reliable predictors of a business recession. Although the signal from the trough of the unemployment rate occurs on average one month before the yield curve inversion, an economic analyst is nonetheless never sure that a trough has occurred. Indeed, the unemployment rate can move up and down over the expansion. For example, from October 1962 to February 1963, the unemployment rate rose from 5.36 percent to 5.95 percent, only to resume falling afterward. By contrast, the yield curve has the advantage that the economic analyst or policymaker does not have to wonder whether an inversion has occurred. But false positives have also occurred with the yield curve, such as the one that occurred in 1966.

Overall, both indicators tend to be reliable signals of a coming recession. But as with all recession signals, the wise economic analysts should examine many indicators rather than betting the farm on one or two. 


\section{ECONOMIC Synopses}

\section{Notes}

1 See Wheelock and Wohar (2009) for a recent survey of the literature on this topic. See also recent St. Louis Fed On the Economy Blog posts by Michael McCracken (https://www.stlouisfed.org/on-the-economy/2018/february/indicators-saying-about-potential-recession) and Michael Owyang and Hannah Shell (https://www.stlouisfed.org/on-the-economy/2016/march/ is-yield-curve-signaling-recession).

2 See the NBER website for dates of U.S. business expansions and contractions (recessions): http://www.nber.org/cycles.html.

${ }^{3}$ See this recent presentation by James Bullard: https://www.stlouisfed.org/ from-the-president/speeches-and-presentations/2017/assessing-yield-curve.

${ }^{4}$ Since June 1954, the average monthly change in the unemployment rate is -0.003 percent, with a standard deviation of 0.18 percent.

\section{Reference}

Wheelock, David C. and Mark E. Wohar. "Can the Term Spread Predict Output Growth and Recessions? A Survey of the Literature." Federal Reserve Bank of St. Louis Review, September-October 2009, 91(5), pp. 419-40. 